\title{
Seroprevalence of transfusion transmissible infections among blood donors at tertiary care hospital in southern Telangana- A 3 year cross sectional study
}

\author{
Dhanashree P Inamdar ${ }^{1, *}$ B Anuradha ${ }^{2}$ \\ ${ }^{1}$ Associate Professor, ${ }^{2}$ Professor and HOD, Dept. of Microbiology, Mamata Medical College, Telangana, India
}

*Corresponding Author: Dhanashree P Inamdar

Email: dhanashreeltmmc@gmail.com

Received: $29^{\text {th }}$ August, 2018

Accepted: $18^{\text {th }}$ September, 2018

\begin{abstract}
Introduction: Transfusion of blood and blood products is lifesaving in clinical situations but sometimes it is also a potential source of infection to patients who receive it. Screening for TTIs (Transfusion Transmissible Infections) have a significant role in in preventing morbidity and mortality of patients receiving blood from blood banks.

Aims and Objective: To determine seroprevalence of transfusion transmissible infections among blood group donors in Khammam district of Telangana.

Materials and Methods: A Retrospective cross sectional study was carried out on all donors in blood bank of a tertiary care hospital at Mamata Medical college, Khammam for three years. Screening tests for HIV (Human Immunodeficiency Virus), HBV (Hepatitis B Virus), HCV (Hepatitis C Virus), Malaria and Syphilis included Rapid and ELISA test kits.

Results: Among 5757 donors, 5674 (98.5\%) were male and 93(1.5\%) were female donors. Overall seroprevalence in a 3 years study showed positivity of $0.42 \%$ in $\mathrm{HBV}, 0.01 \%$ in $\mathrm{HCV}, 0.07 \%$ in HIV. More of younger age group donors of $20-25$ years were seropositive in HIV, whereas for HBV it was 26-30 years age group. O+ve was the commonest blood group observed showing seropositivity in all three. None of the patients were positive for syphilis or malaria in 3 years study period.

Conclusion: We conclude that seroprevalence of HBV was significantly higher than other infections in our area. Seropositivity for Syphilis and Malaria was not seen in our area.
\end{abstract}

Keywords: Transfusion transmissible infections (TTI), Seroprevalence, HIV, HBV, HCV.

\section{Introduction}

Blood transfusion is an essential part of medical treatment and blood transfusion services have vital role in any hospital settings. ${ }^{1-3}$ Morbidity in many clinical diseases and conditions can be reduced by blood transfusion but potential risk of TTIs associated with it cannot be ignored. An apparently healthy donor can also transmit an infection during asymptomatic phase, which leads to increase in prevalence of various infections in general population. ${ }^{4,5}$ Transmission of infectious diseases through donated blood is hazardous as major infections such as Hepatitis, HIV, Syphilis, and malaria can be potentially transmitted to a healthy recipient. ${ }^{6,7}$ In some cases, viral infections such as Cytomegalovirus, Herpes virus, and Epstein-Barr virus along with Toxoplasmosis and Brucellosis may be transmitted. ${ }^{8}$

This makes vigilant screening of blood donation a mandatory process. Economical burden increases with TTIs as it increases the medical cost for newly diagnosed case, his dependency on family members, decreases productivity of affected person with mental burden to him and his dependants. Although it cannot be projected to entire population the trends and prevalence of infections among healthy individuals may be monitored and estimated by screening of TTIs among blood donors which gives a rough estimate of increasing or decreasing trend in TTI in given area. ${ }^{9}$

\section{Materials and Methods}

A retrospective cross-sectional study was carried out on all voluntary donors in blood bank of a tertiary care hospital at Mamata Medical College, Khammam for three years period from January 2015 to December 2017. Screening tests for HIV, HBV, HCV, Malaria and Syphilis included rapid and ELISA test kits.

Pre-donation Screening: Donors were screened through strict donor selection criteria which included thorough history taking about past illness, medical treatments, high risk behaviour, time since last donation if any, etc., along with brief physical examination In physical examination, vitals like temperature, blood pressure, pulse \& respiratory rate were recorded. According to regulations, haemoglobin levels had to be above $12.5 \mathrm{gm} \%$, weight above $45 \mathrm{~kg}$, age between 18 to 60 years. For females, history of menstruation, last pregnancy/delivery and history of lactation was taken. Donor contact information in the form of phone number or e-mail was noted. A written consent was taken from every donor. Then every unit of blood taken was screened for HCV, HBsAg, HIV, syphilis \& malaria.

Serum samples were screened for TTIs:

1. For anti-HIV IgG and IgM antibodies, ELISA method using fourth-generation Microlisa HIV Ag and $\mathrm{Ab}$ detection Kit by Transasia, Pvt., Ltd.

2. For HBV, Hepalisa Microwell ELISA kit by Transasia Pvt. Ltd. 
3. For anti-HCV IgG and IgM, third-generation HCV Microlisa Microwell ELISA kit by Transasia, Pvt., Ltd.

4. For Treponema pallidum-card test by RPR, Beacon diagnostic Pvt., Ltd.

5. For Malaria, using Malaria card test by Parahit Total, Arkray healthcare Pvt., Ltd.

\section{Results}

During the study period, a total of 5757 donors were screened for TTIs. Majority of the screened donors belonged to 20-35 age group. Among them, $5674(98.5 \%)$ were males and $93(1.5 \%)$ were females (Table 1). Out of 5757 screened donors overall seroprevalence of HBV was $0.42 \%$, followed by HIV $0.07 \%$ and $\mathrm{HCV} 0.01 \%$ (Table 2). Majority of the seropositive cases belonged to $\mathrm{O}+\mathrm{ve}$ blood group (Table 3). None of the females were seropositive for HIV, HBV and HCV. Urban distribution was more common among seropositive donors for HIV and HBV and rural in HCV. Majority of seropositive donors of HBV and HCV belonged to 26-30yrs and in HIV belonged to 20-25 age group. Fig. 1 and 2 show average seroprevalence and seroprevalence trends of HIV, HBV and HCV in three years study period (2015-2017). In our study, the prevalence of TTIs showed a decreasing trend of HIV whereas an increasing trend of Hepatitis C and Hepatitis B. Malaria and Syphilis serology was negative in three years study period.

Various studies have been done on HCV seroprevalence (Table 4). Our study showed low prevalence as only one case was positive during three year study period.

Table 1: Year wise blood donation

\begin{tabular}{|l|c|c|c|}
\hline Year & Male Donors & $\begin{array}{c}\text { Female } \\
\text { Donors }\end{array}$ & $\begin{array}{c}\text { Total } \\
\text { Donors }\end{array}$ \\
\hline 2015 & $2031((98 \%)$ & $39(2 \%)$ & 2070 \\
\hline 2016 & $1863(98.5 \%)$ & $27(1.5 \%)$ & 1890 \\
\hline 2017 & $1780(99.05 \%)$ & $17(0.05 \%)$ & 1797 \\
\hline Total & $5674(98.5 \%)$ & $93(1.5 \%)$ & 5757 \\
\hline
\end{tabular}

Table 2: Seropositive \& seroprevalence

\begin{tabular}{|c|c|c|c|c|c|c|c|c|}
\hline Year & HBV+Ve & $\begin{array}{c}\text { Prevalence } \\
\text { (HBV) }\end{array}$ & HCV+ve & $\begin{array}{c}\text { Prevalence } \\
\text { (HCV) }\end{array}$ & HIV+Ve & $\begin{array}{c}\text { Prevalence } \\
\text { (HIV) }\end{array}$ & $\begin{array}{c}\text { Sero } \\
\text { Negative }\end{array}$ & $\begin{array}{c}\text { Total } \\
\text { Donors }\end{array}$ \\
\hline 2015 & $12(0.6 \%)$ & 0.50 & 0 & 0 & $3(0.2 \%)$ & 0.15 & 2055 & 2070 \\
\hline 2016 & $4(0.2 \%)$ & 0.21 & 0 & 0 & 0 & 0 & 1886 & 1890 \\
\hline 2017 & $8(0.5 \%)$ & 0.45 & $1(0.1 \%)$ & 0.06 & $1(0.1 \%)$ & 0.06 & 1787 & 1797 \\
\hline Total & $24(0.4 \%)$ & 0.42 & 1 & 0.01 & 4 & 0.07 & 5728 & 5757 \\
\hline
\end{tabular}

Table 3. Blood group Vs seropositive cases

\begin{tabular}{|l|c|c|c|c|}
\hline Blood Group & HBV+ve & HCV+ve & HIV+ve & Total \\
\hline A+ve & $3(100 \%)$ & $0(0 \%)$ & $0(0 \%)$ & 3 \\
\hline $\mathrm{B}+\mathrm{ve}$ & $8(100 \%)$ & $0(0 \%)$ & $0(0 \%)$ & 8 \\
\hline $\mathrm{AB}+\mathrm{ve}$ & $2(66.7 \%)$ & $0(0 \%)$ & $1(33.3 \%)$ & 3 \\
\hline $\mathrm{O}+\mathrm{ve}$ & $11(73.3 \%)$ & $1(6.7 \%)$ & $3(20 \%)$ & 15 \\
\hline Total & $24(82.7 \%)$ & $1(3.4 \%)$ & $4(13.8 \%)$ & 29 \\
\hline
\end{tabular}

Fig. 1: Average sero prevalence in study period:(2015-2017)

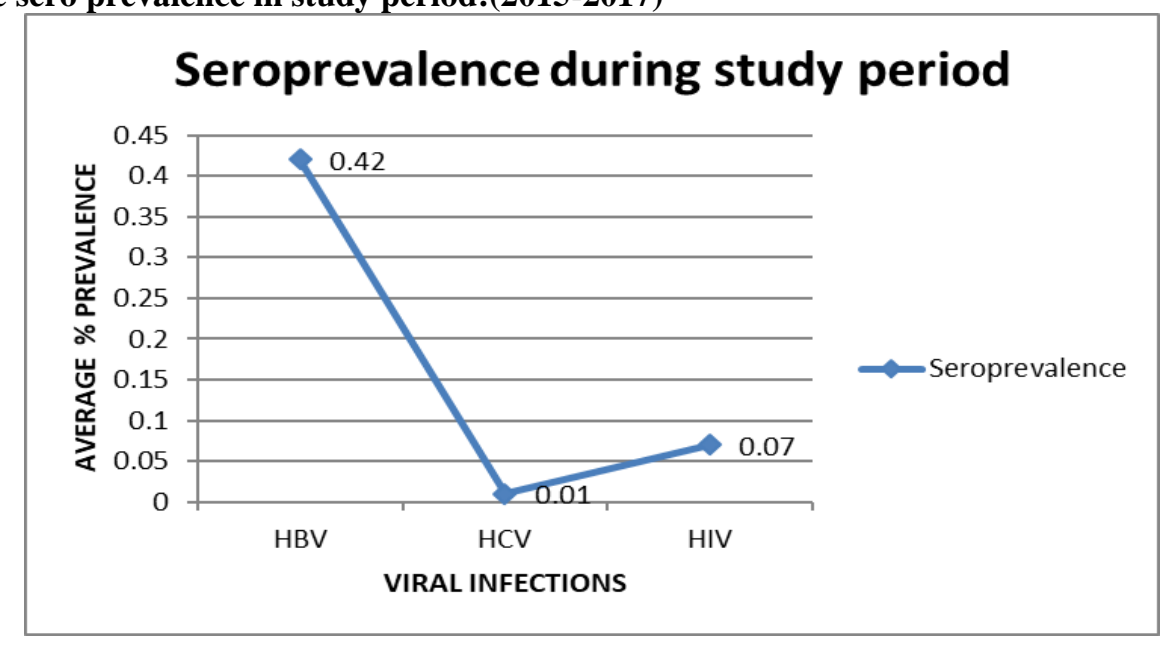


Fig. 2: Seroprevalence trends of HBV, HCV, HIV (2015-17)

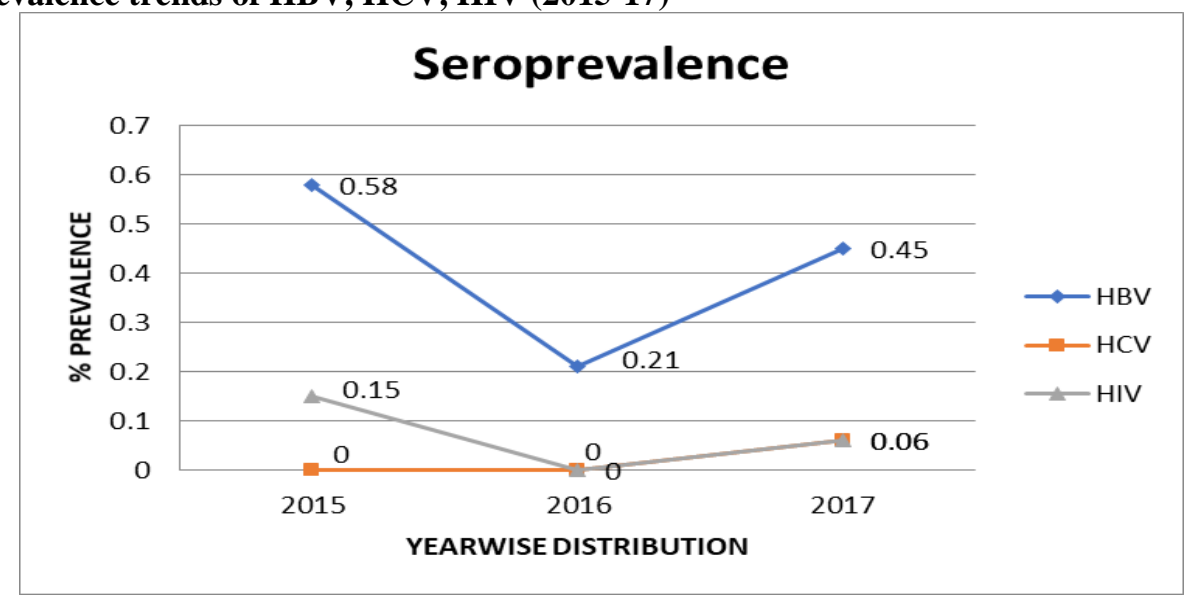

Table 4: Seroprevalence of HIV, HBV, HCV in various studies

\begin{tabular}{|l|c|c|c|c|c|}
\hline Place of study & Year/ donors & $\begin{array}{c}\text { Prevalence of } \\
\text { HIV }\end{array}$ & Prevalence of HBV & $\begin{array}{c}\text { Prevalence of } \\
\text { HCV }\end{array}$ & Reference \\
\hline Dehradun & $2009-12 / 6751$ & $0.13 \%$ & $0.99 \%$ & $0.19 \%$ & 22 \\
\hline Bhopal & $2006-08 / 5008$ & $0.51 \%$ & $2.97 \%$ & $0.57 \%$ & 23 \\
\hline Lucknow & $2012-14 / 39060$ & $0.44 \%$ & $1.27 \%$ & $0.23 \%$ & 24 \\
\hline New Delhi & $2010-12 / 28966$ & $0.56 \%$ & $2.23 \%$ & $0.66 \%$ & 25 \\
\hline Ahmednagar & $2009-10 / 5661$ & $0.07 \%$ & $1.09 \%$ & $0.74 \%$ & 26 \\
\hline Mangalore & $2008-11 / 9599$ & $0.06 \%$ & $0.34 \%$ & $0.06 \%$ & 13 \\
\hline $\begin{array}{l}\text { Present study } \\
\text { (Khammam) }\end{array}$ & $2015-17 / 5674$ & $0.04 \%$ & $0.42 \%$ & $0.01 \%$ & \\
\hline
\end{tabular}

\section{Discussion}

In our study, males $(98.5 \%)$ outnumbered females $(1.5 \%)$ during 3 years study period. This is similar to other studies done in India by Pallavi $\mathrm{P}$ et al, ${ }^{10}$ in which $97.84 \%$ were males, by Patel PA et $\mathrm{al}^{11}$ in which $85 \%$ were males, by Arora D et al ${ }^{12}$ in Southern Haryana.

Out of 5757 screened donors overall seroprevalence of HBV was $0.42 \%$, followed by HIV $0.07 \%$ and $\mathrm{HCV} 0.01 \%$. it is in concordance with the study done by Hilda Fernandes on prevalence of Transfusion Transmitted Infections in Voluntary and Replacement Donors in Mangalore, Karnataka. ${ }^{13} \mathrm{O}+\mathrm{ve}$ blood group was most common among all three seroprevalence in our study as this is because O+ve blood group is the commonest blood group in India.

Urban distribution was more common among patients for HIV and HBV and rural in HCV. Our study is similar to study done by Maria Makuwa et $\mathrm{al}^{14}$ in Africa where they observed seroprevalence more in urban than rural areas and they concluded that this could be due to environmental, behavioral, and cultural factors and migration of patients from rural to urban areas for various reasons which play a role here. Age group of 26-30 years group was commonly affected in HBV and this result is comparable to study done by Dr Ravi Jain in Indore ${ }^{15}$ in 2017 where they observed similar results. Age group of 20-25 years was commonly seen in HIV. Little lesser age group was found to be affected in our study which was in contrast to studies done by BK Das et $\mathrm{al}^{16}$ in Kolkatta in 2011 where higher age group (30-39 years) was affected and Ravi Jain et $\mathrm{al}^{15}$ who observed higher age group affected in HIV. Only one patient was affected with $\mathrm{HCV}$ during our study period belonging to age group of 26-30 yrs.

In our study there is a trend of decreasing seropositivity of HIV from 0.15 to $0.06 \%$ over a period of three years with no positive patients in 2016. Prevalence of HIV has been in decreasing in the Indian population because of the awareness of life threatening disease. ${ }^{16}$ Wide range of HBV seropositivity is also reported from different parts of India which ranges from 1.86 to $4 \%$ (Table 6). Seroprevalence decreased from 2015 to 2016 from 0.58 to 0.21 and again increased to 0.45 in 2017 . HCV seroprevalence during three-year study period was $0.01 \%$. WHO fact sheet showed prevalence of hepatitis $\mathrm{C}$ virus as $0.020 \%$ $(0.003 \%-0.160 \%)$ in high-income countries, $0.320 \%$ $(0.090 \%-0.690 \%)$ in middle-income countries and $1.030 \%(0.670 \%-1.800 \%)$ in low-income countries. ${ }^{17}$ Seroprevalence studies in blood donors can be considered as a reliable tool for statistical estimation of HIV, HBV and HCV infections in the general population as published by Gharehbaghian, Attaullah, et al. ${ }^{18,19}$ But in contrary as per publications by some authors, blood donors cannot be considered as representative of general population. The prevalence rate may be overestimated or underestimated due to 
their different gender, age, area of residence, and other characteristics. ${ }^{20,21}$

\section{Limitations of the Study}

The ideal condition to conduct a seroprevalence study is by taking sample of general population. As blood donors are specifically selected based on extensive questionnaire, strict selection criteria and physical examination and only apparently healthy individuals with lowest risk of TTIs were allowed to donate blood, our study sample does not represent general population. Further, the donor pool was predominantly composed of male population. With merely $1.5 \%$ of female donors, the prevalence cannot be extrapolated to women in this region. We acknowledge the limitation of not using advanced methods like NAAT (Nucleic Acid Amplification Techniques) which are needed for detection of window period in HIV due to non-availability in our blood bank.

In summary our study demonstrates decreasing trend of voluntary blood donation with male predominance. Amongst the blood donors, seropositivity of HBV was highest followed by HIV then HCV. Syphilis and Malaria were seronegative in our study. High seropositivity with significantly increasing trend in 2017 of HBV was observed in the study. It needs further investigation including studying the prevalence rate of $\mathrm{HBV}$ in the general population to address the issue. Decreasing trends with low prevalence of HIV and HCV observed in the study is an encouraging sign supporting the growing awareness of these life-threatening diseases.

\section{Conclusion}

Substantial risk of transfusion-transmissible infections is still prevailing with the current blood transfusion services in our community and ensuring primary prevention of transfusion transmissible infections has a long way to go.

\section{References}

1. Fernandes, H D'souza and D'souza, P.M. Prevalence of Transfusion Transmitted Infections in Voluntary and Replacement Donors. Indian Journal of Hematology \& Blood Transfusion. 2010;26:89-91.

2. Clinical transfusion practice. World health organisation. Available from www.who.int/bloodsafety/transfusion. Clinical Transfusion Practice Guidelines for Medical emergencies.

3. Blood transfusion: the high-risk life-saving therapy. The Free Library. 2011 New Zealand Nurses' Organisation 14 Aug. 2018.Available from https://www.thefreelibrary.com.

4. Sushama A. Chandekar, Gaythri P. Amonkar and Gururaj V. Seroprevalence of transfusion transmitted infections in healthy blood donors: A 5-year Tertiary Care Hospital experience. J Lab Physicians. 9(4):283-287.

5. Sobia Attaullah, Sanaullah Khan, Jabbar Khan. Trend of transfusion transmitted infections frequency in blood donors: provide a road map for its prevention and control. Journal of Translational Medicine. 2012;10:20-22.
6. Grgicevic D, Balija M, Pirc-Tiljak D, Mihaljevic I, Gjenero Margan I, Zupanic-Salek S. Decreasing risk of viral transfusion-transmitted diseases in Croatia. Croat Med J. 2000;41:191-6.

7. Chaudhary IA, Samiullah, Khan SS Masood R, Sardar MA, Mallhi AA. Seroprevalence of HBV and C among health donors at Fauji Foundation Hospital, Rawalpindi. Pak Med J. 2007;23:64-7.

8. Kulkarni N. Analysis of the seroprevalence of HIV, $\mathrm{HBsAg}, \mathrm{HCV}$ and syphilitic infections detected in the pretranfusion blood: a short report. Int J Blood Transfus Immunohematol. 2012;2:1-3.

9. Varsha G Sul, Nandkumar M Deshpande and Pradeep A Gadgil. Seroprevalence of HIV, HBV, HCV and Syphilis among Blood Donors in Western Maharashtra and a Newer Proposed Donor Screening Algorithm. J Blood Disord Transfus. 2017;8:3-5.

10. Pallavi P, Ganesh CK, Jayashree K and Manjunath GV. Seroprevalence and Trends in Transfusion Transmitted Infections Among Blood Donors in a University Hospital Blood Bank: A 5 Year Study. Indian J Hematol Blood Transfus. 2011;27(1):1-6.

11. Patel PA, Patel SP, Oza HV. Seroprevalence of Transfusion Transmitted Infections (TTIs) in blood donors at Western Ahmedabad - a secondary care hospital based study. Int J Biol Med Res. 2012;3:180610.

12. Arora D, Arora B, Khetarpal A. Seroprevalence of HIV, $\mathrm{HBV}, \mathrm{HCV}$ and syphilis in blood donors in Southern Haryana. Indian J Pathol Microbiol. 2010;53:308-09.

13. Hilda Fernandes, Prema Fancy D'souza, Pushpa Maria D'souza. Prevalence of Transfusion Transmitted Infections in Voluntary and Replacement Donors. Indian J Hematol Blood Transfus. 2010;26(3):89-91.

14. Maria Makuwa. Prevalence and Genetic Diversity of Hepatitis B and Delta Viruses in Pregnant Women in Gabon: Molecular Evidence that Hepatitis Delta Virus Clade 8 Originates from and Is Endemic in Central Africa. Journal of Clinical Microbiology. 2008, p. 754 756.

15. Ravi Jain. Transfusion Transmitted Diseases Among Blood Donors in Tertiary Care Teaching Hospital of Central India. Annals of Applied Bio-Sciences. 2017:4(4).

16. Das, B.K., Gayen, B.K., Aditya, S., Chakrovorty, S.K., Datta, P.K. and Joseph, A. Seroprevalence of Hepatitis B, Hepatitis C, and Human Immunodeficiency Virus among Healthy Voluntary First-Time Blood Donors in Kolkata. Annals of Tropical Medicine and Public Health. 2011;4:86-90.

17. Blood safety and availability, WHO, last updated July 2016. Available from http://www.who.int/ mediacentre/factsheets/fs279/en.

18. Gharehbaghian A. An estimate of transfusion-transmitted infection prevalence in general populations. Hepat Mon. 2011;11:1002-3.

19. Attaullah S, Khan S, Khan J. Trend of transfusion transmitted infections frequency in blood donors: Provide a road map for its prevention and control. J Transl Med. 2012;10:20-22.

20. Ali SA, Donahue RM, Qureshi H, Vermund SH. Hepatitis $\mathrm{B}$ and hepatitis $\mathrm{C}$ in Pakistan: Prevalence and risk factors. Int J Infect Dis. 2009;13:9-19.

21. Jafri W, Jafri N, Yakoob J, Islam M, Tirmizi SF, Jafar T, et al. Hepatitis B and C: Prevalence and risk factors associated with seropositivity among children in Karachi, Pakistan. BMC Infect Dis. 2006;6:101-03. 
22. Chattoraj A, Bhel R, Kataria V. Infectious disease markers in blood donors. Med J Armed Forces India. 2008;64(1):33-5.

23. Nilima Sawke, GK Sawke, S Chawla: 'Seroprevalence of common transfusion transmitted infections among blood donors. People's Journal of Scientific Research. 2010;3(1).

24. Pallavi P, Ganesh CK, Jayashree K, Manjunath GV. Seroprevalence and Trends in Transfusion Transmitted Infections among Blood Donors in a University Hospital Blood Bank: A 5 Year Study. Indian J Hematol Blood Transfus. 2011;27(1):1-6.

25. Pahuja S, Sharma M, Baitha B, Jain M. Prevalence and trends of markers of hepatitis $C$ virus, hepatitis $B$ virus and Humany Immunodeficiency Virus in Delhi blood donors. A hospital based study. Jpn J Inf Dis. 2007;60:389-391.
26. Purushottam A. Giri, Jayant D. Deshpande, Deepak B. Phalke, Laximan B. Karle. Seroprevalence of transfusion transmissible infections among voluntary blood donors at a tertiary care teaching hospital in rural area of India. $J$ Family Med Prim Care. 2012:(1):48-51.

How to cite this article: Inamdar D.P, Anuradha B. Seroprevalence of transfusion transmissible infections among blood donors at tertiary care hospital in southern Telangana- A 3 year cross sectional study. Indian J Microbiol Res. 2018;5(4):446-450. 